\title{
The Voices of Berlin: Busking in a 'Creative' City
}

\author{
By Claudia Seldin
}

\begin{abstract}
The city of Berlin is often advertised as one of the most prominent creative cities today. In the past two decades, its marketing agencies have constructed a carefully crafted urban image designed to attract the young, mobile and creative workers that move the contemporary economy. To do that, they rely on cultural temporary uses that enable selected urban spaces to have the desired 'cool' and authentic ambiance that distinguishes this city from others within the competitive global network. This paper investigates the phenomenon of abundant street performers in the German capital to find out if and how these artists perceive their role and instrumentalisation within these creative policies. The field research carried out through the method of ethnography reveals that their understanding of their art as small resistances in urban space often clashes with their use in broader placemaking schemes that have negative consequences. The article begins with a discussion of creative policies in Berlin from an Urban Planning point of view, highlighting how it encourages the migration of young artists and creative professionals. It then analyses the definitions of busking in the existing literature in the Social Sciences to understand its potential as a builder of sociability. Moreover, it draws on theories that speak of the "looseness" of space and the idea of tactically appropriating a place through art to build an interdisciplinary approach between the different fields. Lastly, it presents the case study, using the performers' own testimonials to draw conclusions about the temporary uses of urban space within a broader urban context.
\end{abstract}

Keywords: Berlin, creative policies, resistance, street performance, temporary use

Seldin, Claudia: "The Voices of Berlin: Busking in a 'Creative' City", Culture Unbound, Volume 12, Issue 2, 2020: 233-255. Published by Linköping University Electronic Press: http://www.cultureunbound.ep.liu.se 


\section{Introduction}

It is the first day of spring at the Mauerpark in Berlin, the sun is shining and the city is finally ready to come alive after a longer than usual winter. Right at Eberswalder Straße, the park's main access, I am greeted by a break-dancing group. In the next few hundred meters, I pass a hard rock band, a lone girl singing 60s folk songs, and one of the city's most famous flea markets. A few more steps and I finally reach what I came here to see: the Sunday Karaoke. A small stone circular stage with surrounding amphitheatre, that has somehow become an increasingly popular attraction, is enjoyed by both tourists and locals. Our MC is an excited man on an orange cargo bike with a microphone in hand, who is in charge of introducing the performers and giving them tips on how to engage the audience. The amphitheatre is completely packed, the crowd laughs and applauds as amateurs and professionals alike take the stage. The green piece of land located on the borders of the gentrified neighbourhood of Prenzlauer Berg (see Holm 2013) could not be more different than it was thirty years ago, when it was a "death strip", the empty space between barriers where people would be killed if they tried to cross, of the Berlin Wall. The Mauerpark today is a mirror of much of Berlin in the $21^{\text {st }}$ century: a former urban void turned into a cosmopolitan hub where expats and street performers pop up every day.

As an urban planner, I was astonished to see so many foreign artists in Berlin when I first arrived in 2013, leading me to question whether their presence in this city was at all related to broader cultural and urban planning policies put in place in the 2010s to attract creative workers (see Novy \& Colomb 2013, Seldin 2017). This question about a possible connection drove me to investigate the theme of creative policies in Berlin to understand what the official discourse of urban managers around culture is, especially street performances. After discovering the focus placed on subculture, alternative art and music (Bader \& Scharenberg 2013), I decided to develop a field study to find out if street artists were aware of their indirect use as a tool in this urban branding scheme and what they thought of it.

Written from an urban planning perspective, this article also draws on works from the fields of human geography and anthropology in a transdisciplinary manner to investigate the relationship between creative policies and street performing in Berlin. The main focus here is not to describe in detail the ethnographic study that was developed, but to emphasize how planning policies can instrumentalize artistic practices and often affect their spontaneous character by formalizing and regulating where and when they can happen as part of a larger strategy. What the results of the field research have shown as is that there is a contradiction between how street performers view their contribution to urban life (as small resistances) and how city marketing agencies use them (as tools to sell the image of a subcultural and "authentic" capital). 
The article is structured in the following manner: in consonance with its urban and cultural planning focus, it begins with a brief contextualization of the policies of creativity applied in Berlin in the past years. This city was chosen because it is frequently referred to as a laboratory for urban experimentation (Urban Catalyst 2007, Colomb 2012a, Bernt et al 2013) and because it has gained considerable attention regarding the implementation of creative policies (Bader \& Bialluch 2009, Novy \& Colomb 2013, Seldin 2017). I stress how the building of an image of "authenticity" (Zukin 2011) and subculture has been the main target through its marketing policies and how music and art play a pivotal role in this scheme (Bader \& Scharenberg 2013).

I then present the topic of street performing to highlight how it can contribute to this authentic character by reflecting on some of the definitions in the existing literature in Human/Cultural Geography and Social Anthropology (Campbell 1981, Cohen-Cruz 1998, Tanenbaum 2005, Simpson 2008, 2011, 2012, Kaul 2007, 2014, 2018, Nowakowski 2016). The literature shows that the theme of street performing has been approached from sociological and anthropological angles, but not in relation to urban planning policies. Filling this gap is the primary contribution of this article.

Moreover, to elucidate the relationship between urban space and cultural production from the perspective of Urbanism, I draw on two references that stress the importance of improvisation in public urban spaces: the quality of "looseness" (Franck \& Stevens 2007) and the "tactics of the everyday life" (de Certau 2014). These references help illustrate the point of view of the interviewed artists who perceive themselves as small points of resistance within today's cultural industry. I also pair these concepts with considerations made by Bauman (2003) and Harvey (2011) around sociability in public spaces in contemporary times with the goal of illustrating how street performances could indeed contribute to more interaction in today's metropolises.

I then present the field study, which was conducted in Berlin for nine months using ethnography as a main method, including interviews, and participant observation. The methodology also involved the analysis and interpretation of behaviours (responses to performances), visual data and documents regarding street performing in Berlin in the triangulated way proposed by Kirner and Mills (2020: 203-218) to show how performers see themselves in the city. This study was paired with the analysis of official documents (i.e. busking permits, manifestos, marketing brochures), iconographic material (i.e. posters, videos) and online platforms put together by networks of artists. What was perceived is that the creative city trend as an urban phenomenon in Berlin is a complex one, involving social actors that are both for and against the instrumentalization of creativity for placemaking and economic purposes. In general, local urban managers are 
the ones reinforcing such policies, whose outcomes can include displacement and gentrification (see Lees et al. 2008, Holm 2013). Ironically, the affected population frequently consists of those who help build the image of creativity in the first place (Seldin 2015). These are often artists who play a dual role as both agents and victims of the exclusionary processes of spatial production in contemporary cities. Considering this dual role, this article also examines how street performing can act as both a kind of passive resistance and an enabler to the creative policies that have taken over.

\section{Berlin's Creative Policies: A City for the Young and 'Cool'}

The city of Berlin has always been of interest to the field of Urbanism due to its peculiar history, which has been marked by wars and destruction, the separation between two antagonistic political and economic systems, and the presence of a wall that ensured its duality. In the last two decades, however, its image has begun to change through a process of full instauration of capitalism (Bernt et al 2013) and the implementation of global trends of urban renewal projects with the goal of regenerating degraded areas and urban voids through cultural facilities (Lange et al. 2008, Colomb 2012a, Seldin 2017). The city began to restructure its policies with the goal of transforming itself to one of the most sought-after cultural and creative destinations in Europe. The creative focus could be perceived through the discourse of former mayor Klaus Wowereit (2001-2014):

Since the fall of the Wall in 1989, Berlin has become a dynamic, tolerant, culturally diverse metropolis. Things are looking up for the economy, and the city's open-minded atmosphere draws talented people from all over the world. [...] Excellent education for all, an outstanding location for academics, science, and research, high-quality childcare, affordable housing, a unique range of cultural offerings, creative development potential, and a sense of community and solidarity - all of that goes hand in hand in Berlin. (Senate Chancellery 2014)

During his tenure, Wowereit relied heavily on policies centred on the controversial "creative class" theory by Richard Florida (2002), encouraging young people, artists and creative workers to flock to the city. The idea of a "Creative Berlin" represented a new placemaking tool to push it to a higher position on the competitive global network (Novy \& Colomb 2013).

The concept of creativity seems to have gained momentum in the last two decades (see Landry \& Bianchini 1995), becoming embedded into public policies 
around the globe, implying new rules to guide urban planning and aiming at building highly competitive city images. Florida (2002) mentions the advent of creative capital as the new driving force of urban economy and proposes that the "winning" cities of contemporary global competition should strive to attract professionals linked to the emerging creative industry, essential for the economic growth of today's knowledge-based societies. These professionals would make up a heterogeneous group that includes artists, IT personnel, entrepreneurs and scientists. This group is characterized as bohemian, cool, diverse, tolerant, young and highly mobile; the latter meaning that they can choose where to live in the world. Their choice, according to Florida (2005), is based on the availability of a high quality of life and a specific set of amenities, including an exciting music scene. For Krätke (2011), that reflects the transition from a society based on the production of consumer goods to the production of specialized services and knowledge. A key point of that attraction of the producers of 'creativity' is making cities appear to be "authentic" (Hirsch 2010, Zukin 2011, Kaul 2018).

It is worth noting that the controversy surrounding Floridas (2002) theory has been significant (see Peck 2005, Bader \& Bialluch 2009, Seldin 2015), especially regarding its exclusionary character, the differentiation between urban 'winners' and 'losers', the combining of very different people into one homogenous group, and the glorifying of a gentrifying group as brave urban explorers (Rosler 2010). Despite its exclusionary character, today's urban managers have embraced the discourse that praises creative cities as economy motors, focusing their efforts on building urban spaces that are attractive to the new economy drivers. That has been the case of Berlin, as indicated by Chancellor Angela Merkel:

The American scientist Richard Florida investigated this and came across three factors: technology, talent and tolerance. Only when all three factors come together can we succeed in sustainably growing in future fields. [...] what good news for Europe, what a good maxim for our actions. Technology, talent and tolerance-Europe thrives on innovation. (Merkel 2007)

The same idea is reflected through mayor Wowereit's now (in)famous quote about Berlin being "poor but sexy" during a 2004 TV programme, meaning the city was bankrupt, but possessed a cultural image that could be economically exploited. To achieve that, local marketing agencies (see Berlin.de; Visit Berlin) put together an image of subculture, where buskers, cafés, nightclubs, graffiti and squats merged to generate the desired 'cool'/'authentic' factors. Other actions taken to consolidate the 'Creative Berlin' were the concession of visas to foreign creative workers; the inclusion of Berlin as a member of UNESCO's Creative Cities Network; the 
creation of the 'be Berlin' city slogan; and the State support of start-ups and creative clusters (Seldin 2017). The official English-language brochure by the Senate for Integration and Migration reflects these policies:

Berlin needs immigration and is delighted with the ideas, experiences, and potential that new inhabitants bring with them here to their new home. [...] Berlin is exciting. Berlin is cosmopolitan. Berlin is diverse. I hope that you will also come to appreciate the international character of the city and that you will help to enhance the relaxed and respectful sense of community here. (Senatsverwaltung fur Arbeit, Integration und Frauen 2013: 07)

Bader \& Scharenberg (2013: 245) claim that Berlin's creative industry grew over $23 \%$ between 2000 and 2005, generating approximately 18.5 billion euros. They stress that the alternative music scene has been particularly important, as it is responsible for the accumulation of the "subcultural capital" necessary to the desired subversive urban image.

According to Kaul (2014) and Simpson (2011), street performers have an important role in generating this cultural capital for European cultural cities. My empirical research shows that in Berlin they can help build a subcultural ambiance because their presence in the landscape implies experimentation, the exchange of new ideas and the establishment of audacious cultural networks. Such a notion is reinforced in the placemaking guidebook of the City at Eye Level-a European urban planning initiative for the "improvement" of urban spaces. In the book, Doumpa \& Broad (2016) speak of busking as a planning tool which can "rejuvenate" spaces at low costs, neglecting the negative effects of the instrumentalisation of this artistic practice in the name of urban branding:

Buskers (a.k.a. "street performers") are a viable tool for rejuvenating public spaces. If done well, busking is a high-impact, low-cost option. No infrastructure is needed, no barriers, no ticket sales, no marketing, no strategy sessions; just an artist, who doesn't need a salary, performing for tips. And they can start tomorrow. Buskers prompt social interaction on the street level, create intimacy and allow people feel comfortable and safe. They also provide one of the few forms of live entertainment that low-income citizens can access and enjoy. (Doumpa \& Broad 2016: 113)

Some recent studies even suggest that background music can transform the experience and the ambience of public spaces to make them more sellable (see 
Oakes \& Warnaby 2011). In that sense, the presence of street performers in Berlin has become an indirect contribution to the creation of desirable urban spaces, whether they are aware of it or not. Many of the interviewed performers were attracted to Berlin's reputation as a 'cultural hub', usually setting up camp at the 'cool' former fringe districts between East and West, such as Kreuzberg and Neukölln, which are part of the map of gentrification presented by Holm (2013). Some of them even claimed to have come to this city attracted by the promise of a cosmopolitan ambience in a way similar to what is proposed by Adam Kaul, who speaks of a "philosophical concern with 'authenticity"' by the tourists (Kaul 2007: 703) and of "a cosmopolitan sense of place" derived from busking (Kaul 2018). But what can street performing actually do for urban spaces?

\section{About Busking and Public Space}

Simpson (2011: 416) defines street performance as a set of diverse cultural activities carried out in search of some donation by passers-by and whose artistic and performative character is constantly underestimated. Performance, according to him, consists of an embodied activity capable of transgressing, resisting and defying social structures, since the artists intervene in both the spatial and the temporal organization through dynamic, mutant and living events, capable of changing the flows of people. In a less idealized manner, Kushner \& Brooks (2000) view street performance as an economic and consumer exchange "in which producer and consumer spend time together; [...] the performer delivers artistic service in return for a fee paid by the audience" (Kushner \& Brooks 2000: 65).

According to Broad et al (2014: 02), founders of the online platform The Busking Project (n.d.) busking is one of the oldest professions in the world and the term "to busk" refers to the verb "buscar" in Spanish, which means "to search". That implies that street artists were originally recognized for their relationship with urban space and mobility, with the act of seeking the next place to perform, the next audience, the next way of sustaining themselves financially.

As for the history of buskers in Europe, Paul Simpson (2015) highlights the figure of the medieval minstrel, stressing that he probably had the patronage of a "great man" and, therefore, some protection to travel more freely. Without this support, it would have been very easy to be considered just an outlaw. Being in constant motion made people feel that these individuals did not fit into the common social structures and into a world where belongings and frontiers were essential. That is, for centuries and to this day, the act of making art in public space is tied to uncertainties, rejections and the need for permission to express oneself in the place that should, at least theoretically, belong to everyone. 
The relationship between street performance and public space is interesting because public space is a concept of utter importance in the field of Urbanism due to its symbolic dimension. That is the place of experimentation, of dialogue and of coexistence with others, with difference. Serpa (2014) defines it as the place of "reproduction of different ideas of culture, of an (inter)subjectivity that connects subjects and perceptions in the production and reproduction of banal and everyday spaces" (Serpa 2014: 11). He affirms that public space should be the place of communicational action, where democracy happens. So, in Urbanism, public space is ideally seen as the space of possibilities, but it is worth noting that the streets have never been totally free or democratic and that several groups are often excluded or censured directly or indirectly from the places that should belong to all (see Cohen-Cruz 1998).

In fact, when analysing busking in British cities, Simpson (2011) perceives a type of "domestication" of space that aims at preventing the lack of civility. Madanipour (2017) similarly mentions the frequent surveillance and the social norms in the open spaces of London, reflecting the control of spontaneous activities in public space, making sure that practices deviating from the everyday routines remain temporary. This leads me to stress the controversial perceptions around street performers in public spaces even in Berlin, where observation shows their acceptance to be high. Still, some interviewed passers-by claimed they were "too loud", or "a nuisance".

Certain behaviours and practices can often be deemed as negative presences in public spaces of cities worldwide, i.e. beggars and the homeless. Historically, artists too have often been perceived as such people (see Harisson-Pepper 2010; Hawkins 2011) and, to this day, they can be seen by some as unwanted disruptions of the everyday lives.

Still, regardless of some controversial opinions from passers-by, in terms of urban placemaking, street performing seems to configure the type of temporary use that has been glorified within urban planning practices in Berlin since the mid-2000s (see Urban Catalyst 2007). There, cultural uses and artistic occupations have become a trend incorporated in policies by the State and land developers, often with speculative motives, because they can call attention to certain sites, attracting renters and buyers (Colomb 2012b). In many ways, busking can be perceived as a very low-cost and short-term interim land use that fits well with the romanticized idea of certain planning professionals that view temporary urbanism as 'miraculous' trend that increases sociability and encourages participatory activities in public spaces (see Oswalt et al 2014). 


\section{Tactics of Spatial Appropriation Through Culture: Busking and the Urban Sphere}

Street performances have thus an interesting contradictory role in Berlin today because they contribute to its carefully-crafted image as a creative hub for creative workers, while also encouraging social interactions and a type of resistance in public spaces. To reflect upon the complex relationship between art, temporary uses and urban space, I draw on Franck and Stevens's (2007: 02) concept of "loose spaces", which have the power to harbour spontaneous, often unplanned activities.

The existence of "loose spaces" is possible through anthropic activities and the ability of people to perceive and apprehend their potential, to see new possibilities for their use. This ability can also be linked to the notion of creativity, but not to the same type mentioned by Florida (2002), which often implies the commodification of work for economic profit within urban policies. In this case, creativity means innovative ways to use and re-use space, reinventing its functions. This is not a new discovery, but part of the processes of production and appropriation of space that have always existed in cities worldwide. In that sense, the creativity linked to "loose spaces" is not always connected to the production of cultural and cognitive capital that benefit only a few; but rather to a quality that resides in the perception of the flexibility of spaces. The lack of permanence leads to a somewhat transgressive character, an idea of doing something that can go against what has been socially accepted or established, against the norms or even the laws. Through the diversity and multiplicity of urban actors, the existence of "loose spaces" allows certain identities to flourish (Franck \& Stevens 2007: 20-21). One of these is street performing.

Street performing is, however, not only a means to activate "loose spaces", but also a potential social tactic. For Cohen-Cruz (1998), some "radical street performances" can even "question or re-envision ingrained social arrangements of power". He states that they can carry a sense of utopia, because the performances "strive to transport everyday reality to something more ideal. [...] [creating] a bridge between imagined and real actions" (Cohen-Cruz 1998: 01). For him, the audience acts as "witnesses" faced with "a social act that one does not know how to change but must at least acknowledge" (Cohen-Cruz 1998: 06). This view can be linked to de Certeau's (2014) concept of tactics of the everyday life if we consider that street artists can act outside the imposed order of the creative/ cultural industry and the formal market. Faced with the obstacles of daily life, they must find solutions to share their art and earn their living by (re)appropriating the streets according to the given possibilities, subverting references and norms, and often opening cracks in the pre-established power relations. I call this a tactic because for de Certeau, "[the tactic] takes advantage of 'opportunities' and depends on them" (de Certeau 2014: 94). Making art in a public space can mean 
deviating from the routine, breaking the monotony of urban life and tactically triggering the attention of others.

Many activities associated with spatial 'looseness' revolve around forms of leisure, entertainment, expression or interaction. The unexpected presence of performers on the streets can lead to new human connections, special moments, and the interruption of flows of people in the name of emotional involvement. In this sense, it neutralizes the growing indifferent attitude that some authors, such as Bauman (2003) and Harvey (2011), perceive in contemporary times when speaking about the crisis of modernity. Bauman (2003) stresses a growing emphasis on individualism and even solitude, which are the product of a "blasé attitude" created as a defence mechanism for people to deal with the many and rapid transformations happening in all spheres of life, including the rapid urbanization that has drastically changed their immediate space of coexistence. He states that this often leads to individualism being mistaken for the need to create a prominent identity of distinction among the masses - an idea that resonates with Zukin's (2011) writings on "authenticity". Practices like street performing can be perceived as ways of breaking patterns of disengagement, as proposed by Tanenbaum (2005), who links busking in New York to public trust, diversity and racial cooperation.

In fact, the field research in Berlin showed that this cooperation happens not only between performers and audience, but also between performers themselves. Since most of them are constantly moving through different cities, they often build networks in which experiences are shared on what are the best and worst places to perform. Within this network, Berlin is spoken of as a city of high acceptance, as also confirmed by the online platform 'Berlin Street Music' (Berlin Street Music). It is disclosed as a "mecca for artists and creatives alike", a place where busking is met with admiration, recognition and the possibility of securing a livelihood outside the standards imposed by the formal musical industry. Berlin is also a city where other EU citizens can live, and where people with a good knowledge of English can get by while speaking little to no German. This positive reputation coupled with policies for the migration of certain professionals led to an increase in the number of foreign artists moving to the city (see Senate Chancellery 2014).

\section{Busking in Berlin: A Case Study}

\section{Methodological notes}

With the goal of understanding how Berlin street performers saw themselves in relation to creative policies, field research was carried out for nine months. It consisted of indirect observation and periodic semi-structured interviews with 
12 street performers. I specifically chose artists who could draw big crowds (and were thus able to speak about their tactics of successfully attracting and engaging a local audience), spoke English (either as a first or second language, to enable the interviews), were not born in Berlin, and would fit Florida's (2002) description of the young, mobile, cool and bohemian "creative class." I approached each of them after seeing their performances in specific places advertised through urban marketing tools, such as official city portals. I followed those willing to be interviewed and who would be staying in Berlin for a period of five or more months, so that I could gather insights on their change in perception over time.

While the main focus of the research was street performance in general, the majority of interviewees were actually musicians. The questions asked were designed to get an understanding of their reasons for choosing these specific areas, their perception of the Berlin audiences in comparison to their hometowns, their goals in terms of monetary gain, and their opinions of local busking laws and of what makes for a bad or good busking experience in public or semi-public spaces, among others. Each participant was followed two to three times during their performances, which made possible the observation of the reactions between performers and public, people and spaces, all registered in an observation log. I opt here to refer to the interviewees only by their first names to protect their privacy.

Around 83 percent of the approached performers were non-Germans, which highlighted the diversity of the local street performers, as previously stated by Nowakowski (2016). This finding enabled a deeper investigation into their reasons for moving to Berlin and the differences between performing in their hometowns and in this city: "Berlin is different than other cities. There are more creative opportunities here than in our city", claimed New Zealander actors and musicians Chloe and Elliott, implying they had been attracted to the creative discourse in place, even if they were not directly aware of it.

From the urban planning point of view, it was even more important to select the artists in relation to the specific place where they chose to play. The interviewees had to play in areas that had undergone some sort of urban renewal project or had been somehow incorporated in the creative strategies of local urban marketing agencies (see Berlin.de). These areas included the Mauerpark, Alexanderplatz, Hackescher Markt, the surroundings of the Friedrichstraße Station and Bergmannstraße; all located in the districts of Pankow/Prenzlauer Berg, Friedrichshain, Kreuzberg and Mitte, which are advertised as the hip and young neighbourhoods that make up 'Creative Berlin'. Pankow/Prenzlauer Berg (home of the Mauerpark) is described by the portal VisitBerlin as "cool, creative and cosmopolitan", the headline for Friedrichshain-Kreuzberg is "alternative lifestyles and creativity", while Mitte is seen as "cosmopolitan and typically Berlin" (Visit Berlin). 


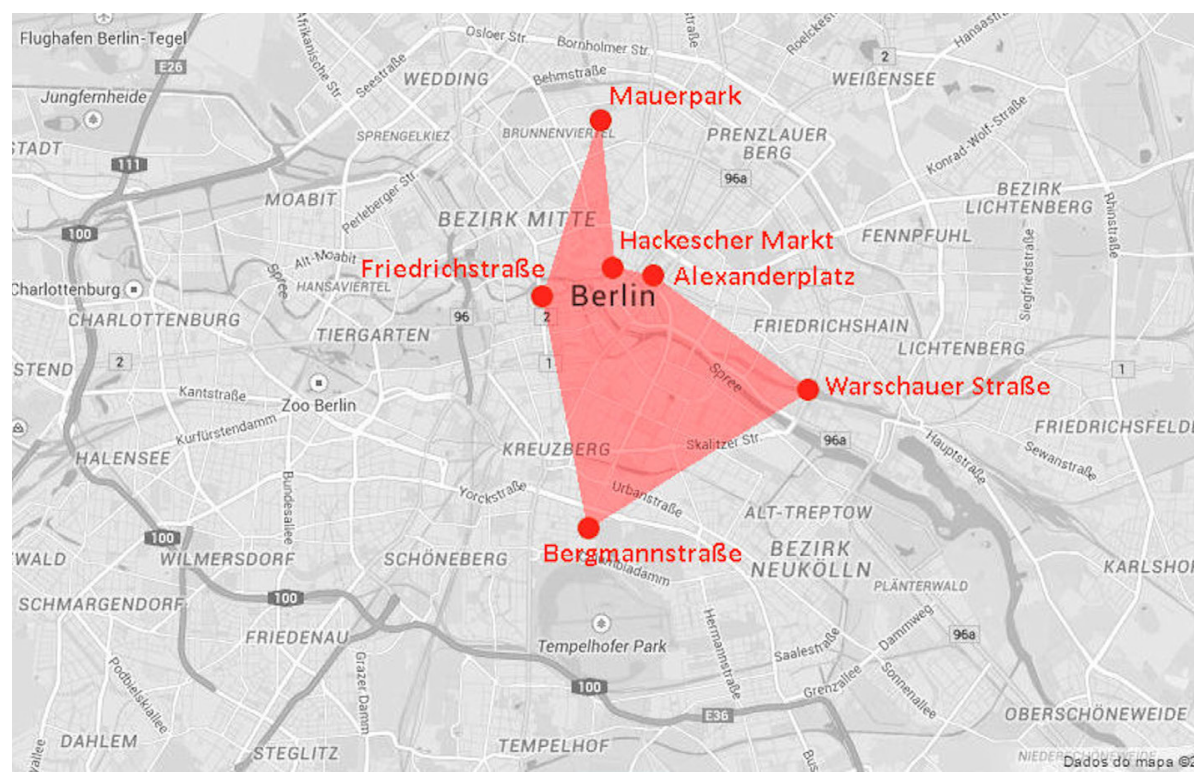

Figure 1. The preferred area for buskers in Berlin.

Observation of the performers also took place in festivals with larger audiences to establish comparisons with solo performances. These festivals, which also happened within the selected districts, are incorporated in the city's creative narrative as events that promoted diversity and tolerance. They included the Berlin Lacht (Berlin Laughs) festival and the Karneval der Kulturen (Carnival of the Cultures) - this last one self-described as a "joyful statement for an open and intercultural society", where street art meets the selling of products originated from countries worldwide (Karneval der Kulturen).

The observation of street festivals as part of the methodology is relevant because they attract large audiences and enable a closer encounter between viewers and artists. It was observed that because the artists' presence there is already expected, anticipated and deemed to be accepted by the law, people feel more comfortable approaching the performers to listen, watch and even to contribute financially to their activities. Below, I structure the results of the case study through the following topics: busking as (a small) resistance; busking and monetary issues; busking and laws, culture and land value. The interviews, the field $\log$ and observations were paired with considerations present on the existing literature in an effort to better interpret the overall perception of the participants about their role in urban space and their connection to creative polices. 


\section{Culture Unbound}

\section{Busking in the artists' eyes}

When it comes to the perception of their roles in public space, the artists showed a rather romanticized view of themselves and their impact on urban space, implying their role as small resistances in the everyday life of the city. According to Australian singer-songwriter Jackson, "one of the advantages of street performing is the ability to shorten the distance between the artist and the audience", a view endorsed by Hirsch (2010). Many of the artists interviewed in Berlin agree that by gathering a small group of spectators, a new and temporary sociability emerges, modifying the dynamics of space at that moment in a positive manner. For US bass-player Nick, what happens through busking is the establishment of a "neighbourhood feeling". He mentioned that street performing allows for the emergence of a "connection between people and the city", further stating that it is a "very inclusive activity".

Like Nick, some of the other interviewees claimed that they had little to no busking experience in their hometowns and that the city of Berlin inspired them to pursue the activity. It is easy to perceive an idealized view of the German capital and of street performing in Nick's eyes, in a manner similar to Tanenbaum's (2005) account of subway music in New York, when he recounts his personal experiences with busking in big cities of the USA:

[...] there is more room for improvisation and for free entertainment in Berlin. People here are more open to get closer to an artist they do not know and to create a vibration, new relationships, new connections. (Nick, USA)

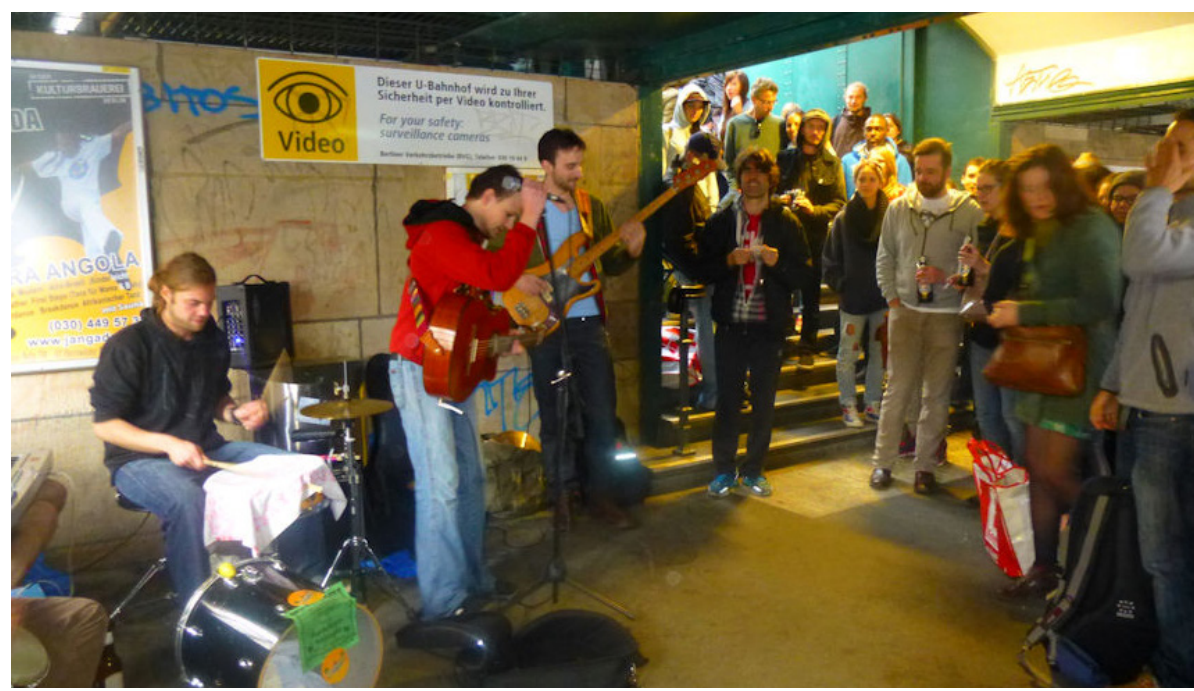

Figure 2. A band of Latin rhythms inside a train station in Prenzlauer Berg in 2013. 
But comparisons between Berlin and the artists' hometowns are not always glamourized and involve concerns about how they fit into a larger economic scheme and monetary concerns. Ecuadorian musician Byron, for instance, showed some discomfort when asked directly about his role as part of the local cultural tourism strategies:

I have noticed many differences between playing in Latin America and in Europe. The music I used to play in Latin America was more traditional. I didn't use to play for foreigners, like in here. In Berlin, I play more for tourists and my sound is stereotyped as a Latin sound. On the other hand, there seems to be a better perception of street performers here than in some cities in South America. But Berlin is too full of street performers right now. There are good ones, but also many bad ones and that can hurt the street performers' reputations. (Byron, Ecuador)

He stated, however, that playing music in the streets "does make him feel more like a part of a city [where he was not born]." He believes that, to some extent, busking can help break down barriers between Germans and foreigners, functioning as the type of disruption to daily routines proposed by Simpson $(2008,2012)$.

Byron's discomfort about his role in tourism was somewhat echoed by Swedish singer Hanna. Even though she pointed to Berlin as a popular destination for some European performers because Berliners are more accustomed to a "tip culture" than in Scandinavia, she seemed to reject having her music being perceived as a touristic attraction. She then claimed that her favourite spot to perform was "a small square close to Bergmannstraße because there are a lot of people there, but not many tourists". What she did not consider is that Bergmannstraße's is one of the trendy locations in the city, basically a poster-street for the attraction of the creative class, as it is beloved by the type of resident that falls in a category between the tourist and the German dweller, as publicized by the local marketing agencies:

Bergmannstraße is the lively heart of this neighbourhood and is one of the most vibrant in the entire city. Especially on weekends, the countless passers-by and residents enjoy the range of products at the busy Markthalle and also love browsing through the thrift stores and fashion boutiques. The cafés and restaurants offer everything from Thai cuisine to Turkish specialities and even fresh American-style muffins and bagels. (Visit Berlin) 
Hanna's different social perceptions were not limited to questions of nationality but also of gender. She stated that there are very few women performers on the streets and that this can reflect today's society and the music industry itself, which has historically benefited male artists. In this sense, street performing could also be perceived as a way of tactically acting against the formal creative industry's tendencies of benefiting a certain look, genre or even gender. It can be a way of making art and standing your ground regardless of what is in vogue now.

\section{Busking and monetary issues}

Almost all of the other interviewees mentioned the relationship between busking and the music industry. For them, performing on the streets is generally a way to leave behind the logic of the dominant cultural industry, which promotes only the more saleable rhythms. According to Jason, busking can be a more efficient way of promoting one's own music, independent of record labels that control which artists get the most publicity. This view was also shared by New Zealander singer-songwriter Ryan, who claimed that publicizing his work was more important than receiving tips:

Just stopping to listen and enjoying [the performance] is great. The money is important too of course, but most of the enjoyment comes from people listening. I don't like selling CDs, I think it's an outdated form of media. I would rather give my music away for free or for an online donation, like a download. (Ryan, New Zealand)

This kind of opinion led to the understanding that most artists featured in this study could not be considered as part of a socially vulnerable group because they are not performing their art primarily for the reason of generating an income, as Byron states:

I think I'm over the stage of playing for money alone. The ideal for me would be to merge making money with the pleasure of playing. [...] The main satisfaction for me is not really the money, but of course it is a valid "qualifier". The most important for me is to convey the music. I never want to stop playing on the streets ... even if one day I became famous. For me, playing on the streets is a luxury. (Byron, Ecuador)

As posed by Bywater (2007) and Hirsch (2010), some street artists often have difficulty defining themselves as buskers who ask for money, tending to see themselves on 'the threshold between one steady condition and another"' (Hirsch 2010: 352). They oscillate from describing their activities as a means of getting 
extra money to an art form; as a means of artistic self-education ("busking helped strengthen my voice", says Ryan) to psychological enlightenment or betterment ("I now feel more confident in front of people I don't know", says Hanna). The multiples definitions lead to the conclusion that street performing in Berlin can truly embody all of these goals, helping demystify the idea of the busker as mere beggars, confirming Juricich (2017)'s view. However, it seems important to highlight that most of the interviewees had other sources of income. Many taught private music classes, some even holding university degrees, making it clear that street performing for the selected group in the study is a choice and not a necessity. In that sense, they do reflect the somewhat privileged group of artists that would make up Florida's (2002) "creative class", being highly mobile and choosing in which city to live due to its authentic ambience, 'cool' factor and economic possibilities.

Their experience contrasts with those who actually engage in panhandling through busking in the German capital. My research showed that panhandlers in Berlin usually take the form of lower-income immigrants carrying around amplifiers playing background music on loop and singing along, directly requesting donations. They often occupy the city trains in shorter intervals of time (between one station and another), disrespecting the local laws and being badly perceived by many of the interviewees. This brings about the question of personal appearance of the street performance in order to be "socially accepted" and implies some judgment regarding the quality of the performance in question.

In more romanticized accounts by Campbell (1981), McMahan (1996) and Tanenbaum (2005), busking is perceived as an often-homogenous act that disregards the different and divergent goals of the artists (artistic, monetary and so on). However, Patricia Campbell (1981) highlighted early on that many of the classical music street performers, for instance, were university students with goals more aligned with rehearsing than monetary gain. That is also true in today's Berlin and in many other metropolises, where "aesthetic preferences and altruism in response to supplication play important roles in determining willingness to pay" (Kushner \& Brooks 2000: 66).

The field research showed that not only artistic modality and musical style were important to the level of "acceptance" of the performers, but also their personal characteristics, like ethnicity, spoken language and even religious choice, proving that "aesthetic preferences, social preferences, and situational aspects" do play a significant role for street performing, as posed by Kushner \& Brook (2000: 67). This observation leads to the conclusion that Berliners are not always as tolerant to diversity as described in the official brochures that glorify it as a creative paradise, and that the panhandlers here are more akin to the type of Floridian "service class" that passers-by would rather ignore. The panhandlers presence might also serve 
as a constant reminder of questions that locals would rather not have to ask, such as "do these immigrants have options other than busking for a living?"; "what are their social conditions in this country?; "why are they not fully integrated with the rest of the Berliners?", and so on.

Still, one should be careful when contrasting the studied buskers and 'panhandlers' and their economic roles by following blindly controversial and simplifying theories like Florida's (2002). The truth is that, while buskers contribute substantially to the cool ambiance and subcultural image of certain areas in Berlin, they do have a rather small economic role within the local creative industry, which focuses on the more lucrative sectors of design, communication and informatics (see Seldin 2017). In the case of the music industry, Berlin is internationally known for styles like techno and electro (Bader \& Scharenberg 2013), strongly targeting its nightclub scene. In many ways, street performers have become a secondary concern when it comes to the Berliner music economy. As evidence of this, in 2017, conservative politicians felt the need to discuss tax reductions for techno nightclubs as a means to keep alive what they called a "night economy", in the face of rising real estate developments (AFP 2017). While some busking laws are always discussed in administrative contexts, street performers rarely gain the level of attention in those discussions as the money-spinning and tourist-magnet night scene.

\section{Busking and laws. Culture and land value}

Most interviewed performers spoke of busking laws and restrictions as very necessary, though they question some excessive aspects of the local bureaucracy, especially those connected to permits, as stated in the platform Berlin Street Music -an online manifesto and handbook for busking in the city, offering explanations into zone regulations.

Although many interviewees mentioned the presence of more tolerant laws towards street artists in Berlin in comparison to other European metropolises, such as London, recent years have brought about more restrictions to the activity. Some of these restrictions can be interpreted as forms of control of street art and even as attempts to 'clean' or shape the city's image. In April of 2014, local authorities passed a law banning street performers dressed as film and TV characters, and human statues dressed as war soldiers in front of the Brandenburg Gate-one of the city's most popular sights (Gander 2014). Musicians and caricaturists continue to be allowed on the spot, leading to the question of how far the public power should be responsible for defining what kind of art is legitimate and where it should be publicly displayed.

More recently, the transport company BVG put up signs inside the U-Bahn underground railway stations designating areas were busking is allowed. An 


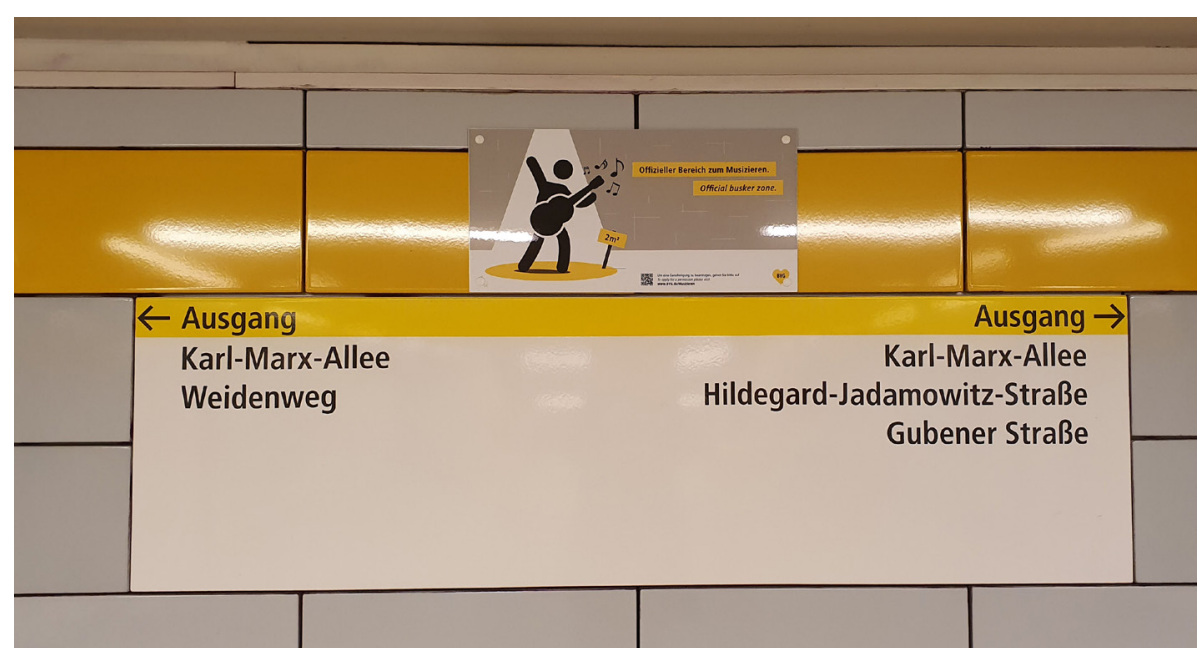

Figure 3. Sign inside the Weberwiese underground station in 2019, where busking activities are rare: "official busker zone". Photo by the author.

interesting observation is that the signs are not only German, but also in English, and that many were put up in stations were busking is not common, leading to the question of whether the city is trying to encourage performances in strategically pre-chosen areas and in a controlled fashion.

The State's tendency to select what kind of art is useful or profitable for the consolidation of an attractive urban image and where this art should take place leads to the conclusion that street performing and other cultural temporary uses can act as tools for creative policies, depending on where and how they occur and who benefits from them.

One example of the negative consequences of temporary cultural uses in urban planning is the increasing land and real estate speculation that can come with raising attention to a former neglected site, as is the case with Mauerpark. This former no man's land adjacent to the Berlin Wall was cited as a favourite busking site for many of the interviewees and it is clear to see that it is completely transformed in spring and summer due to the presence of temporary users, responsible for changing the local ambience.

This fact has not gone unnoticed by land speculators, who have tried to develop projects for luxury flats in the surrounding areas for years. They have been fighting against local associations, such as the Friends of the Mauerpark, who view it as "a social, cultural, and artistic centre of the city" (Freude des Mauerparks e.V.). Through multiple temporary cultural uses, this former no man's land has been turned into a vivacious place, full of meaning for different people. Still, its future is uncertain. During the completion of this article in 2019, a new dispute was taking place at Mauerpark, as the administration of the district of Pankow considered not granting their annual karaoke permit. While they claimed potential security risks were posed by local construction works, critics alleged that the real reason for the permit delay was the complaints by some residents about the noise and the 


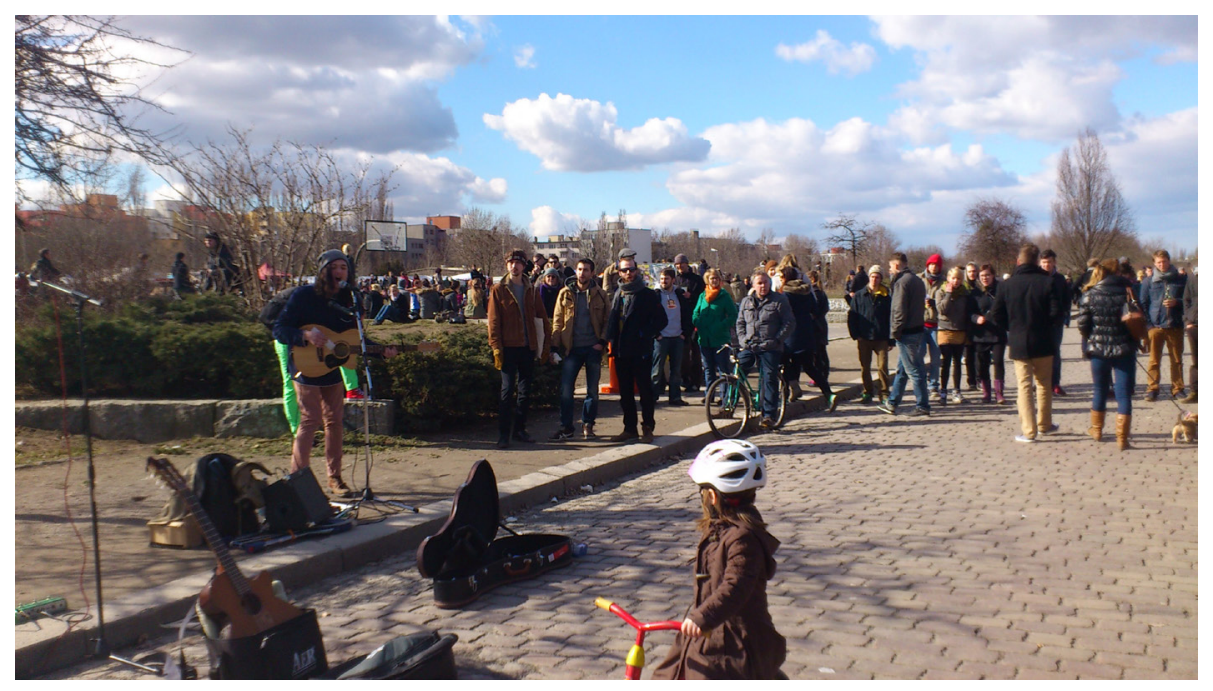

Figure 4. Celebration of the first day of spring at the Mauerpark in 2013. Photo by the author.

presence of too many tourists. This assumption was backed by a spokesperson for the construction company, who ensured that tunnels had been sufficiently secured and posed no danger to the visitors (DPA 2019). These diverging views around the Mauerpark and its artistic uses reflect the contradiction that is inherent to creative cities of the early twenty-first century, where different urban players have diverging goals of land use for their own benefit.

\section{Conclusions}

Berlin is one of the clearest examples of the twenty-first century's policies towards creative cities. For almost two decades, it has experienced an intensification of measures and policies that encourage the creation of an image of an alternative and tolerant city that welcomes young artists and subcultural experiences. As a result, the practice of street performing by foreign performers has increased immensely, marking the local landscape and giving vitality to the local public spaces.

The field research has shown the connection between street performing in Berlin and the strengthening of a notion of cosmopolitanism and "authenticity" that is key to the construction of a very specific urban image and its ability to drive today's economy. The idea of this image is further spread by a network of performers, who share a mixture of idealized mental pictures of what Berlin is like and what the ideal ambience for street performing should be. These pictures are often guided by broader creative discourses and by a contemporary desire to 
search for "authentic" and "real" experiences-a yearning that has become part of an internationally shared mind-set when it comes to cultural consumption, as argued by Zukin (2011). In this context, "the liminality of the street performer shifts as a marker of low status to one of symbolic value-a value that corresponds to contemporary markers of authenticity", as Hirsch (2010:354) puts it.

In Berlin, however, the street performances acquire a contradictory and complex role, which can contribute with both positive and negative consequences to the larger picture of urban planning and space reproduction in contemporary times. On one hand, they act as a catalyst for more sociability in public spaces while allowing some artists to succeed tactically outside the formal cultural industry and to create new social and economic relationships on the micro-level. They are able to give back to the city its vitality and to allow people to relax, observe, celebrate and even protest. They can contribute to the existence of heterogeneity, to the exercise of the right to participation and appropriation of space, and they are necessary to assure the diversity of experiences in the city.

On the other hand, street performers-as part of the larger trend of cultural temporary uses in urban planning-can be instrumentalized in the making of a carefully constructed urban image with specific economic goals that benefit only a few. Within broader creative policies, they can also end up playing a role in exclusionary outcomes that include gentrification, real estate speculation, and the selection of what kind of art and cultural practices are allowed in the city and where they can take place.

In conclusion, the pairing of space 'looseness' and culture in a temporary manner equals a combination that appears to be harmless but can consist of a smart tactic or a strategy, depending on the point of view of the urban actors in question.

\section{Acknowledgements}

Funding for this study was financed by the "Coordenação de Aperfeiçoamento de Pessoal de Nível Superior (CAPES-Brazil)" (Finance Code 001) and by the Alexander von Humboldt Foundation (Germany).

Claudia Seldin is an architect and urbanist with a Ph.D. in Urbanism from the Federal University of Rio de Janeiro (UFRJ) and two collaborative periods at the Bauhaus-Universität Weimar. She currently holds a Capes-Alexander von Humboldt postdoc fellowship at the Center for Metropolitan Studies of the Technische Universität Berlin in Germany. Her current research interests include: creative cities, temporary and cultural appropriations of space and placemaking policies in Europe and Latin America. E-mail: claudia.seldin@metropolitanstudies.de 


\section{Culture Unbound}

Journal of Current Cultural Research

\section{Notes}

${ }^{1}$ By acceptance, I speak of the number of people stopping by to watch or listen to the performances and of the amount of donations received by the artists -observed in the field $\log$.

\section{References}

AFP (2017): “"The Night Economy': How Even Conservatives are Trying to Protect Berlin Techno", The Local, 14 December 2017: https://www.thelocal.de/20171214/ the-night-economy-how-even-conservatives-are-trying-to-protect-berlin-techno, (accessed 10/28/2019)

Bader, Ingo \& Martin Bialluch, (2009): "Gentrification and the Creative Class in Berlin-Kreuzberg", Libby Porter \& Kate Shaw, (eds): Whose Urban Renaissance?, London: Routledge, 93-102.

Bader, Ingo \& Albert Scharenberg, (2013): "The Sound of Berlin. Subculture and Global Music Industry", Matthias Bernt et al., (eds): The Berlin Reader, Berlin: Transcript, 240-260.

Bauman, Zygmut (2003): Community, Rio de Janeiro: Zahar.

Berlin.de - das offizielle Haupstadtportal, https://www.berlin.de/, (accessed 05/23/2018)

Bernt, Matthias; Britta Grell \& Andrej Holm. (2013): "Introduction", Matthias Bernt; Britta Grell \& Andrej Holm, (eds): The Berlin Reader, Berlin: Transcript, 11-21.

Broad, Nick; Belle Crawford \& Nick Smith (2014): The Busking Project, London: Torque.

Bywater, Michael (2007): "Performing Spaces: Street Music and Public Territory", Twentieth-Century Music, 3.1, 97-120.

Campbell, Patricia J. (1981): Passing the Hat: Street Performers in America, New York: Delacorte.

Cohen-Cruz, Jan (1998) (ed): Radical Street Performance, London: Routledge, 1-6.

Colomb, Claire (2012a): Staging the New Berlin, London: Routledge.

Colomb, Claire (2012b): "Pushing the Urban Frontier: Temporary Uses of Space, City Marketing, and the Creative City Discourse in 2000s Berlin", Journal of Urban Affairs, 34.2, 131-152.

de Certeau, Michel (2014): L'Invention du Quotidien I, Petrópolis: Vozes.

Doumpa, Vivian \& Nick Broad (2016): "Street Performing: Low Cost, High Impact", Karssenberg, Hans et al. (ed): The City at Eye Level, Delft: Eburon, 113-115.

DPA (2019): “No More Karaoke in Mauerpark?", Berlin.de, 13 March 2019: https:// www.berlin.de/en/news/5704688-5559700-no-more-bearpit-karaoke-in-mauerpark.en.html, (accessed 07/28/2019).

Franck, Karen \& Quentin Stevens (2007): “Tying Down Loose Space”, Karen Franck \& Quentin Stevens (eds): Loose Space, New York: Routledge, 01-33.

Florida, Richard (2002): The Rise of the Creative Class, New York: Basic Books.

Florida, Richard (2005): Cities and the Creative Class, New York: Routledge.

Freunde des Mauerparks e.V., https://www.mauerpark.info/freunde-des-mauerparks-ev/15-year-commitment/?lang=en, (accessed 10/30/2019).

Gander, Kashmira (2014): "Berlin Bans Mickey Mouse and Darth Vader from Brandenburg Gate", The Independent, 15 April 2014: www.independent.co.uk/ news/world/europe/berlin-bans-mickey-mouse-and-darth-vader-from-brandenburg-gate-9263016.html, (accessed 02/28/2018).

Harrison-Pepper, Sally (2010): Drawing a Circle in the Square, Jackson: University Press of Mississippi. 


\section{Culture Unbound}

Journal of Current Cultural Research

Harvey, David (2011). The Condition of Postmodernity, São Paulo: Loyola.

Hawkins, Robert (2012): "Industry Cannot Go On without the Production of Some Noise", Journal of Social History, 46.1, 106-123.

Hirsch, Lily (2010): “Playing for Change': Peace, Universality, and the Street Performer", American Music, 28.3, 346-367.

Holm, Andrej (2013): "Berlin's Gentrification Mainstream", Matthias Bernt; Britta Grell \& Andrej Holm, (eds): The Berlin Reader, Berlin: Transcript, 171-187.

Juricich, John (2017): “Freeing Buskers' Free Speech Rights: Impact of Regulations on Buskers' Right to Free Speech and Expression", Harvard Journal of Sports \& Entertainment Law, 8.1, 39-62.

Karneval der Kulturen, https://www.karneval.berlin/de/karneval/was-ist-der-kdk. html, (accessed 11/01/2019).

Kaul, Adam (2007): "The Limits of Commodification in Traditional Irish Music sessions", Journal of the Royal Anthropological Institute, 13.3, 703-719.

Kaul, Adam (2014): "Music on the Edge: Busking at the Cliffs of Moher and the Commodification of a Musical Landscape", Tourist Studies, 14.1, 30-47.

Kaul, Adam (2018): "A Cosmopolitan Sense of Place: Busking, Tourism and Performance in "The City of Strangers", Robert Shepherd (ed), Cosmopolitanism and Tourism, Maryland: Lexington, 3-23.

Krätke, Stefan (2011): The Creative Capital of Cities, Oxford: Wiley-Blackwell.

Kirner, Kimberly \& Jan Mills (2020): Introduction to Ethnographic Research. Thousand Oaks: Sage.

Kushner, Roland \& Arthur Brooks (2000): “The One-Man Band by the Quick Lunch Stand", Journal of Cultural Economics, 24, 65-77.

Landry, Charles \& Franco Bianchini, (1995): The Creative City, London: Demos.

Lange, Bastian; Ares Kalandides; Birgit Stöber \& H. A. Mieg (2008): "Berlin's Creative Industries: Governing Creativity?", Industry and Innovation, 15:5, 531-548.

Lees, Loretta; Tom Slater \& Elvin K. Wyly (2008): Gentrification, New York: Routledge.

Madanipour, Ali (2017): Cities in Times, New York: Bloomsbury.

McMahan, Jane (1996): "Subway Performance: An Excavation", Journal of Popular Culture, 29.4, 159-180.

Merkel, Angela (2007). "Speech at the European Parlament." Straßburg, 17 January 2007: https://www.bundesregierung.de/breg-de/service/bulletin/rede-von-bundeskanzlerin-dr-angela-merkel-797836, (accessed 10/27/2019).

Nowakowski, Mark (2016): Straßenmusik in Berlin, Bielefeld: Transcript.

Novy, Johannes \& Claire Colomb (2013): "Struggling for the Right to the (Creative) City in Berlin and Hamburg", International Journal of Urban and Regional Research, 37.5, 1816-1838.

Oakes, Steve \& Gary Warnaby (2011): "Conceptualizing the Management and Consumption of Live Music in Urban Space", Marketing Theory, 11.4, 405-418.

Oswalt, Philipp; Klaus Overmeyer \& Philipp Misselwitz. (eds) (2014): Urban Catalyst: The Power of Temporary Use, Berlin: Dom.

Peck, Jamie (2005): "Struggling with the Creative Class", International Journal of Urban and Regional Research, 29.4, 740-770.

Rosler, Martha (2010): “Culture Class: Art, Creativity, Urbanism”, e-flux, 21.

Seldin, Claudia (2015): "Práticas Culturais como Insurgências Urbanas: o Caso do Squat Kunsthaus Tacheles em Berlim", Revista Brasileira de Estudos Urbanos e Regionais, 17.3, 68-85.

Seldin, Claudia (2017): Imagens Urbanas e Resistências: Das Capitais de Cultura às Cidades Criativas, Rio de Janeiro: Rio Books.

Senate Chancellery (ed.) (2014): 25 Years After the Fall of the Wall. Berlin, Press and Information Office. Senatsverwaltung für Arbeit, Integration und Frauen (2013): Wilkommen in Berlin, Berlin: AZ. 


\section{Culture Unbound}

Journal of Current Cultural Research

Serpa, Angelo (2014): O Espaço Público na Cidade Contemporânea, São Paulo: Contexto.

Simpson, Paul (2008): "Chronic Everyday Life: Rhythmanalysing Street Performance", Social \& Cultural Geography, 9.7, 807-829.

Simpson, Paul (2011): "Street Performance and the City: Public Space, Sociality, and Intervening in the Everyday", Space and Culture, 14.4, 415-430.

Simpson, Paul (2012): "Apprehending Everyday Rhythms: Rhythmanalysis, Time-Lapse Photography, and the Space-Times of Street Performance", Cultural Geographies, 19.4, 423-445.

Simpson, Paul (2015): "The History of Street Performance", https://www. gresham.ac.uk/lectures-and-events/the-history-of-street-performance, (accessed 03/01/2018).

Tanenbaum, Susie (2005): Underground Harmonies: Music and Politics in the Subways of New York: Cornell University Press.

The Busking Project (n.d.), https://busk.co/, (accessed 04/14/2020).

Urban Catalyst (2007): Urban Pioneers. Temporary Use and Urban Development in Berlin, Berlin: Jovis.

Visit Berlin - Berlin's Official Travel Website, https://www.visitberlin.de/en, (accessed $11 / 01 / 2019)$

Zukin, Sharon (2011): Naked City, New York: Oxford University Press. 